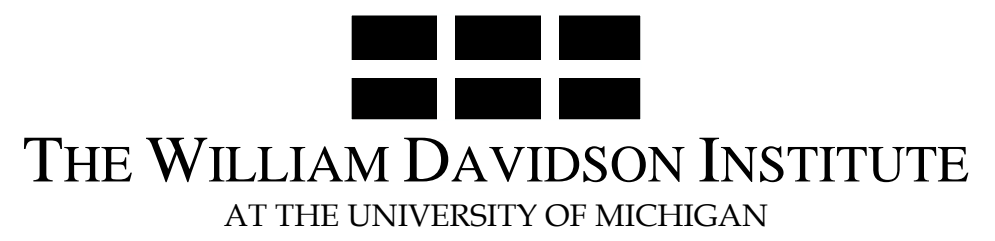

AT THE UNIVERSITY OF MICHIGAN

\title{
TRADE SPECIALISATION AND ECONOMIC CONVERGENCE: EVIDENCE FROM TWO EASTERN EUROPEAN COUNTRIES
}

\author{
By: Christophe Rault, Guglielmo Caporale, Robert Sova \\ and Anamaria Sova
}

William Davidson Institute Working Paper Number 959

June 2009 


\title{
TRADE SPECIALISATION \\ AND ECONOMIC CONVERGENCE: \\ EVIDENCE FROM TWO EASTERN EUROPEAN COUNTRIES
}

\author{
Guglielmo Maria Caporale \\ Brunel University (London), CESifo and DIW ${ }^{1}$ \\ Christophe Rault \\ LEO, University of Orléans ${ }^{2}$ \\ Robert Sova \\ CES, Sorbonne University, A.S.E. and E.B.R.C ${ }^{3}$ \\ Anamaria Sova \\ CES, Sorbonne University, and E.B.R.C ${ }^{4}$
}

June 2009

\begin{abstract}
This paper analyses trade specialisation dynamics in two Eastern European countries (Romania and Bulgaria - EEC-2) vis-à-vis the core EU member states (EU-15) over the period 1990-2006. Specifically, we focus on whether there is a shift towards intra-industry trade leading to economic convergence and technological catch-up. We use recently developed static (FEM, REM and FEVD) and dynamic (GMM) panel data methods which take into account possible heterogeneity. Our empirical results indicate that intra-industry trade has indeed increased, but it is of the vertical rather than the horizontal type, resulting in complementary rather than competitive production patterns.
\end{abstract}

Keywords: gravity models, panel data models, trade specialisation, comparative advantage JEL Classification: F13, F15, C23.

\footnotetext{
1 Centre for Empirical Finance, Brunel University, Uxbridge, Middlesex UB8 3PH, UK. Email: Guglielmo-Maria.Caporale@brunel.ac.uk.

2 University of Orléans, LEO, CNRS, UMR 6221, Rue de Blois-B.P.6739, 45067 Orléans Cedex 2, France; email: chrault@hotmail.com.web-site: http://chrault3.free.fr/ (corresponding author).

3 Center of Economics Studies Paris I, 106-112 bd. de L'Hôpital, 75647 Paris Cedex 13, France, and Academy of Economic Studies, Bucharest, Economic \& Business Research Center E-mail: robertsova@yahoo.com.

4 Center of Economics Studies Paris I, 106-112 bd. de L'Hôpital, 75647 Paris Cedex 13, France, and Economic \& Business Research Center, E-mail: anamariasova@yahoo.fr.
} 


\section{Non-Technical Summary}

Even after Romania and Bulgaria, two Eastern European countries (EEC-2 henceforth), became EU members in 2007, long-term economic convergence has remained an important goal for them (Albu, 2008; Iancu, 2008). The EU enlargement, by bringing together developed and transition economies, is generally expected to lead to higher intra-industry trade through technology transfers, and therefore to economic convergence, which is typical of regionalisation (see Lundberg, 1992; Fontagné and Freudenberg, 1997, Fidrmuc and

Djablík 2003). Economic integration also leads to the international diffusion of knowledge and convergence in the quality of traded goods, with a positive effect on exports (Cavallaro and Mulino, 2008). There is in fact a wide consensus in the literature that intra-industry trade is more conducive to economic growth than inter-industry trade, and that the former tends to take place between countries with similar factor endowments (Helpman, 1987), to stimulate innovation and to exploit economies of scale (Ruffin, 1999). Given the fact that there is a positive correlation between GDP growth and intensity of intra-industry trade, new EU members hope to achieve higher growth rates and sustainable development as a result of an increase in intra-industry trade with the other members.

International trade specialisation reflects differences in relative factor productivity and endowments, economies of scale or specific advantages of firms. It is not neutral, and it can have a significant impact on economic growth. Countries that converge normally export products whose share in international trade is increasing. By contrast, those diverging typically exhibit inertia, and have comparative advantages in products whose share of world trade is stable or declining. Competitiveness is primarily a result of comparative advantages at the microeconomic level as well as of product innovation and differentiation.

This paper analyses trade specialisation dynamics of a set of heterogeneous economies by exploiting recent advances in panel data econometrics. Our sample includes data on the EU15 (the core of the EU) and the EEC-2, which have many similarities and entered the EU as part of the last wave of 2007. The issue of interest is whether EU membership has resulted in the EEC-2 continuing to specialise in inter-industry trade based on their comparative advantage resulting from lower labour costs, or instead their moving towards intra-industry specialisation which leads to economic convergence. Although convergence towards the other EU-15 members is the aim of the EEC-2 countries, significant differences in labour costs and 
technological level ${ }^{5}$ may lead to a reallocation of labour-intensive industries from the EU-15 to the EEC-2 as part of the international division of the production process.

Our empirical analysis over the period 1990-2006 is based on economic indicators and the econometric estimation of a gravity model, which is suitable for both intra- and inter-industry trade. We use recently developed static and dynamic panel data methods, which explicitly take into account unobserved heterogeneity. Specifically, we use the fixed effect and random effect models (FEM and REM respectively) as well as the fixed effect vector decomposition (FEVD) technique proposed by Plümper and Troeger (2004), and the system Generalized Moment Method (GMM) estimator developed by Arellano and Bover (1995) and Blundel and Bond (1998). First, we highlight the existence of strong asymmetries in trade relationships between the countries of the two groups (EU-15 and EEC-2). Then we select an appropriate specification of the gravity model and carefully investigate the main determinants of trade flows between these sets of countries.

Our results indicate a shift towards intra-industry trade, specifically of the vertical type: EU multinational firms manufacture products in Romania and Bulgaria exploiting the comparative advantage of low labour costs and then export them. This type of trade increases production and labour productivity, but does not lead to economic convergence, which is associated instead to horizontal intra-industry trade, i.e. to simultaneous export and import flows of comparable size of products with similar quality, technology and value added. In other words, in the context of European integration, the EEC-2 have followed the strategy of exploiting their comparative advantage of low labour costs in the context of the international division of production processes, although some sectors with high value added (e.g., electric and mechanics) have also expanded (similar results were reported by Andreff (1998) for other Eastern European economies as well). Therefore, the challenge for Romania and Bulgaria is to change their production patterns from complementary to competitive and move towards international market segments with high quality and high value-added products, thereby accelerating convergence towards the EU-15.

\footnotetext{
${ }^{5}$ In 2005, hourly labour costs were equal to 2.33 euros in Romania, 1.55 euros in Bulgaria and 25.1 euros in the EU-15 (source: Eurostat).
} 


\section{Introduction}

Even after Romania and Bulgaria, two Eastern European countries (EEC-2 henceforth), became EU members in 2007, long-term economic convergence has remained an important goal for them (Albu, 2008; Iancu, 2008). The EU enlargement, by bringing together developed and transition economies, is generally expected to lead to higher intra-industry trade through technology transfers, and therefore to economic convergence, which is typical of regionalisation (see Lundberg, 1992; Fontagné and Freudenberg, 1997, Fidrmuc and Djablík 2003). Economic integration also leads to the international diffusion of knowledge and convergence in the quality of traded goods, with a positive effect on exports (Cavallaro and Mulino, 2008). There is in fact a wide consensus in the literature that intra-industry trade is more conducive to economic growth than inter-industry trade, and that the former tends to take place between countries with similar factor endowments (Helpman, 1987), to stimulate innovation and to exploit economies of scale (Ruffin, 1999). Given the fact that there is a positive correlation between GDP growth and intensity of intra-industry trade, new EU members hope to achieve higher growth rates and sustainable development as a result of an increase in intra-industry trade with the other members.

International trade specialisation reflects differences in relative factor productivity and endowments, economies of scale or specific advantages of firms. It is not neutral, and it can have a significant impact on economic growth. Countries that converge normally export products whose share in international trade is increasing. By contrast, those diverging typically exhibit inertia, and have comparative advantages in products whose share of world trade is stable or declining. Competitiveness is primarily a result of comparative advantages at the microeconomic level as well as of product innovation and differentiation.

This paper analyses trade specialisation dynamics of a set of heterogeneous economies by exploiting recent advances in panel data econometrics. Our sample includes data on the EU-15 (the core of the EU) and the EEC-2, which have many similarities and entered the EU as part of the last wave of 2007. The issue of interest is whether EU membership has resulted in the EEC-2 continuing to specialise in inter-industry trade based on their comparative advantage resulting from lower labour costs, or instead their moving towards intra-industry specialisation which leads to economic convergence. Although convergence towards the other EU-15 members is the aim of the EEC-2 countries, significant differences in labour costs and 
technological level ${ }^{6}$ may lead to a reallocation of labour-intensive industries from the EU-15 to the EEC-2 as part of the international division of the production process.

Our empirical analysis over the period 1990-2006 is based on economic indicators and the econometric estimation of a gravity model, which is suitable for both intra- and interindustry trade. We use recently developed static and dynamic panel data methods, which explicitly take into account unobserved heterogeneity. Specifically, we use the fixed effect and random effect models (FEM and REM respectively) as well as the fixed effect vector decomposition (FEVD) technique proposed by Plümper and Troeger (2004), and the system Generalized Moment Method (GMM) estimator developed by Arellano and Bover (1995) and Blundel and Bond (1998). First, we highlight the existence of strong asymmetries in trade relationships between the countries of the two groups (EU-15 and EEC-2). Then we select an appropriate specification of the gravity model and carefully investigate the main determinants of trade flows between these sets of countries.

The remainder of the paper is organised as follows. Section 2 provides some background information on trade flows between the EEC-2 and the EU-15. Section 3 outlines the theory behind gravity models. Section 4 presents the econometric model and reports the empirical results. Finally, Section 5 summarises the main findings and discusses their policy implications.

\section{An overview of trade flows between the EEC and EU-15 countries}

Trade patterns between the EEC and the EU-15 countries are still characterised by significant asymmetries which are a heritage of the former communist system which followed an extensive rather than intensive development policy: until 1989, the former group of countries were centrally planned economies where trade was based on monopoly of international trade, import and export planning and currency inconvertibility. Hence, trade mainly took place within the Council for Mutual Economic Assistance. After the fall of the communist regime, these countries adopted instead an open system and Western Europe became one of their most important trade partners. However, trade openness towards Western Europe varied significantly, the relevant index in 1989 being 19.3\% for Romania and 18.4\% for Bulgaria respectively. This reorientation of trade flows towards Western Europe is consistent with the gravity model. Geographical, historical and cultural links played an important role in the

\footnotetext{
${ }^{6}$ In 2005, hourly labour costs were equal to 2.33 euros in Romania, 1.55 euros in Bulgaria and 25.1 euros in the EU-15 (source: Eurostat).
} 
establishment of preferential relationships between the two zones. We are interested in analysing the evolution of trade patterns for the EEC-2 countries since they obtained access to a much wider market.

\subsection{Increasing but asymmetric trade flows}

The framework for trade flows between the EEC-2 and EU-15 is given by the European Agreement of 1993. Its implementation has led to a significant increase in trade volume between these two sets of countries, with both higher exports and imports (see Figure 1, and Table 1 for country and sector codes). In Romania, the trade balance moved from a surplus to a deficit in 1992, and the latter grew over time. Bulgaria has experienced a deficit throughout (see Figure 1 and Table 5). By 2000, weights for trade flows to/from the EU-15 were very close to those for intra-European trade. However, the East-West relationship is asymmetrical as the EEC-2 only play a marginal role in total trade of the EU-15 while the latter are their main partner. The trade deficit reflects a lack of competitiveness of the EEC-2 products compared to the EU-15 ones.

\subsection{The reorientation of EEC trade and structural adjustment}

Next, we examine whether the reorientation of trade towards the EU-15 was accompanied by industrial structural adjustment and convergence of trade specialisation. As can be seen from Figure 2, which shows export weights to the EU-15 by sector, in Romania some sectors (textiles, electric and mechanics) experienced a sharp increase in exports, whilst other did not. In Bulgaria, the textiles and steel sectors were most successful.

Thus, international trade in the case of the EEC-2 still concerns labour-intensive industries. In Romania the weight for exports of the textile sectors has increased from $28.2 \%$ in 1990 to $37.1 \%$ in 2006; in Bulgaria it has risen from $16.2 \%$ to $29.1 \%$ over the same time period. In 1990, in Romania the weights were the following: $21.4 \%$ (energy sector), 28\% (textiles), 19.9\% (woods and paper), 9.3\% (electric and mechanics), 5.4\% (chemicals), and $2.4 \%$ (building materials, agricultural products and food). The figures for 2006 indicate clearly the key role of low labour costs as a comparative advantage, the new weights being: $37 \%$ (textile sector), 34.8\% (electric and mechanics sector). Therefore, reallocations concerned primarily the textile sector, followed by the electric and mechanics sector, where segments of production with assembly operations were particularly developed. The recent increase in the volume of electric and mechanics exports may lead to an improvement in 
Romanian exports to the EU-15, but in general trade remains based on inter-sectoral complementarity. The weights of other sectors have instead declined since 1990: for iron and steel from $8 \%$ to $5.4 \%$, for the energy sector from $21.4 \%$ to $2 \%$, for the woods and paper sector from $19.9 \%$ to $9.1 \%$, for the chemicals sector from $5.4 \%$ to $5.1 \%$, and for food products from $2.4 \%$ to $0.8 \%$ (see Figure 2 and 3 ).

A similar evolution can also be observed in Bulgaria, where the weight of the textile sector has increased from $16.2 \%$ (in 1990) to $29.1 \%$ (in 2006), that of the iron and steel sector from $13.2 \%$ to $23.5 \%$, and that of the electric and mechanic sectors from $12 \%$ to $18.8 \%$. In the other sectors there has been a fall of about $1 \%$. This can be seen as evidence of complementary specialisation.

\subsection{Trade specialisation of the Eastern European Countries}

To shed further light on trade specialisation, we analyse some indicators of (i) comparative advantage and (ii) intra-industry trade.

\subsubsection{Comparative advantages of the EEC}

The analysis of sectoral trade adjustment is based on revealed comparative advantages calculations. Their evolution over time indicates whether trade pattern convergence has occurred.

Balassa (1965) was the first to propose indicators based on trade to measure international specialisation indirectly: he suggested to use export and import flows, and the trade balance. Here we utilise the indicator due to Lafay (1990), where the trade balance is weighted by a country's GDP:

$$
A c k=\left(\frac{1000}{P I B}\right) \frac{2 \times\left(X_{i k} M-X M_{i k}\right)}{X+M}
$$

where:

$\mathrm{A}_{\mathrm{ck}}=$ Lafay indicator;

$\mathrm{X}, \mathrm{M}=$ total exports and imports;

$\mathrm{X}_{\mathrm{ik}}, \mathrm{M}_{\mathrm{ik}}=$ exports and imports of product $\mathrm{k}$;

$\mathrm{PIB}=$ gross domestic product.

This indicator measures the relative contribution of product $\mathrm{k}$ to the overall trade balance. A positive (negative) sign indicates the existence of a comparative advantage (disadvantage). 
Table 2 shows that trade patterns are relatively stable after 17 years of economic catch-up. The most important comparative advantages concern the labour-intensive products, in particular textile products, footwear, wood and paper products. These advantages have increased over time as a result of subcontracting from the EU-15 to the EEC-2, where wages are much lower. The textiles sector appears to have the strongest comparative advantage and the highest degree of specialisation. Generally, capital-intensive sectors have a comparative disadvantage. An example is the electric and mechanic sector, which has a greater disadvantage in Bulgaria than in Romania.

Overall, what emerges from the sectoral analysis is that the comparative advantages of Romania and Bulgaria vis-à-vis the EU-15, and their specialisation, are based on differences in factor endowments. Trade specialisation for the two countries reflects a relatively large and increasing weight of labour-intensive products. Over time, there have been no major changes in export products, and technology-intensive industries with highly-skilled labour have not become competitive.

\subsubsection{Intra-industry trade and competitive pressures}

International trade does not result only from comparative advantages, which imply export and import flows of complementary products, i.e. inter-industry trade (IT), in accordance with classical theory. Intra-industry trade (IIT) also occurs, with simultaneous export and import flows of comparable size within the same industry; this can be either horizontal or vertical. The former is typical of developed countries and is two-way trade in a single industry between products at the same stage in the production process. Vertical intra-industry trade (VIIT) instead concerns products at different stages of the production process.

Generally, regional integration of different economies leads to higher inter-industry trade (IT) based on complementary products but also to vertical intra-industry trade with specialisation in different segments of the production process, with a different unit cost. In our case, it is interesting to establish whether there has been an increase in intra-industry trade for the EEC-2 (Romania and Bulgaria). This is normally associated with economic catching-up, and would indicated integration of EU industrial patterns and hence convergence between the EEC-2 and the EU-15. A widely used measure of intra-industry trade is the traditional GrubelLloyd (GL) (1975) indicator. When this index is close to 1, intra-industry trade dominates, whilst, when the coefficient is close to 0 , trade is predominantly of the inter-industry type.

The GL indicator is defined as follows: 


$$
G L=1-\frac{\sum_{k=1}^{N}\left|X_{i j k t}-M_{i j k t}\right|}{\sum_{k}^{N}\left(X_{i j k t}+M_{i j k t}\right)}
$$

where :

$\mathrm{X}^{\mathrm{k}}{ }_{\mathrm{ijt}}=$ exports of product industry $\boldsymbol{k}$ of country $\boldsymbol{i}$ towards country $\boldsymbol{j}$ in year $\boldsymbol{t}$ $\mathrm{M}_{\mathrm{ijt}}^{\mathrm{k}}=$ imports of product $\boldsymbol{k}$ country $\boldsymbol{i}$ from country $\boldsymbol{j}$ in year $\boldsymbol{t}$

A high share of intra-industry trade suggests advanced economic integration and a high level of industrial development, and can have significant long-term benefits. However, intra-industry trade by itself is not sufficient to characterise the level of technological development and competitiveness, an essential condition to cope with competitive pressures. Indeed, empirical studies have highlighted the existence of two types of intra-industry trade: horizontal and vertical. Trade with horizontally differentiated products is specific to countries which have a high level of development, with high prices incorporating research and development ( $\mathrm{R} \& \mathrm{D})$ costs and significant value added. Vertical intra-industry trade is specific to less developed countries, and it leads to specialisation in less capital-intensive production stages.

We find (see Table $3 a$ and $3 b$ ) a sharp increase in the GL index during the period under investigation, which indicates a growing importance of intra-industry trade, which by 2006 has become dominant, although the index itself does not allow us to distinguish between vertical and horizontal intra-industry trade.

The GL index is a static measure as it captures IIT in one particular year. There is a wide consensus in the literature that IIT entails lower costs of factor market adjustment than inter-industry trade (Balassa 1966). To analyse the dynamic adjustment we use the marginal intra-industry trade (MIIT) measure developed by Brülhart (1994), which is the following:

$$
A=1-\frac{|\Delta X-\Delta M|}{|\Delta X|+|\Delta M|}
$$

The MIIT, as the GL index, varies between 0 and 1, with 0 (1) indicating that marginal trade is entirely of the inter-industry (intra-industry) type.

However, Brülhart's (1994) dynamic index also does not distinguish between vertical and horizontal IIT. To resolve this issue we adopt the method proposed by Thom and McDowell (1999), which differentiates between horizontal and vertical IIT on the basis of the organisation of production rather than goods characteristics. By assuming that industry $\mathrm{J}$ has 
$\mathrm{N}$ sub-industries the following index for horizontal intra-industry (HIIT) can be derived:

$$
A_{w}=\sum_{i=1}^{N} w_{i} A_{i}
$$

where :

$A_{i}$ represents Brülhart's marginal intra-industry trade index for product $i$ of industry $j$;

$$
A_{i}=1-\frac{\left|\Delta X_{i}-\Delta M_{i}\right|}{\left|\Delta X_{i}\right|+\left|\Delta M_{i}\right|}
$$

$\mathrm{X}_{\mathrm{i}}=$ value of export of product $\mathrm{i} ; \mathrm{M}_{\mathrm{i}}=$ value of import of product $\mathrm{i}$

$\Delta \mathrm{X}=\mathrm{X}_{\mathrm{t}}-\mathrm{X}_{\mathrm{t}-\mathrm{n}}$ and $\Delta \mathrm{M}=\mathrm{M}_{\mathrm{t}}-\mathrm{M}_{\mathrm{t}-\mathrm{n}}$ (the difference of export/import between year $t$ and $t-n)$

$\mathrm{W}_{\mathrm{i}}$ are appropriate weights (see Brülhart 1994) defined as :

$$
w_{i}=\frac{\left|\Delta X_{i}\right|+\left|\Delta M_{i}\right|}{\sum_{i=1}^{N}\left(\left|\Delta X_{i}\right|+\left|\Delta M_{i}\right|\right)}
$$

where $X_{j}=\sum_{i=1}^{N} X_{i}$ and $M_{j}=\sum_{i=1}^{N} M_{i}$ and $\mathrm{A}_{\mathrm{j}}$ (the proportion of matched two-way trade at the industry $\mathrm{j}$ level) is given by

$$
A_{j}=1-\frac{\left|\Delta X_{j}-\Delta M_{j}\right|}{\sum_{i=1}^{N}\left|\Delta X_{i}\right|+\sum_{i=1}^{N}\left|\Delta M_{i}\right|}
$$

$A_{j}$ represents vertical and horizontal intra-industry trade. Vertical IIT is given by $A_{j}-A_{w}$ while inter-industry trade (IT) is measured by $\left(1-\mathrm{A}_{\mathrm{j}}\right)$. Our results highlight a shift towards intraindustry trade, especially of the vertical type in the last period (see Table $4 a, b$ ).

Next, in order to shed more light on the type of specialisation of these two countries vis-à-vis the EU-15 we carry out static and dynamic panel data analysis and estimate a gravity model, whose theoretical foundations are outlined in the next section.

\section{The gravity model}

The gravity model is widely used as a benchmark to estimate trade flows between countries ${ }^{7}$. Trade flows from country $\boldsymbol{i}$ to country $\boldsymbol{j}$ are modelled as a function of supply of the exporter

\footnotetext{
${ }^{7}$ Eichengreen and Irwin (1995) consider the gravity model "the workhorse for empirical studies of regional integration".
} 
country, demand of the importer country and trade barriers. In other words, national incomes of two countries, transport costs (transaction costs) and regional agreements are the basic determinants of trade.

Initially inspired by Newton's gravity law, gravity models have become essential tools in the analysis of international trade flows. The first applications were rather intuitive, without theoretical foundations. These included the contributions of Tinbergen (1962) and Pöyhönen (1963). Subsequently, new international trade theory provided theoretical justifications for these models in terms of increasing returns of scale, imperfect competition and geography (transport costs) (see Anderson 1979, Bergstrand 1985, and Helpman and Krugman 1985).

Linnemann (1966) proposed a gravity model based on a Walrasian, general equilibrium approach. He explained exports of country $\boldsymbol{i}$ to country $\boldsymbol{j}$ in terms of the interaction of three factors: potential supply of exports of country $\boldsymbol{i}$, potential demand of imports from the country $\boldsymbol{j}$, and trade barriers. Potential export supply is a positive function of the exporting country's income level and can also be interpreted as a proxy for product variety. Potential import demand is a positive function of the importing country's income level. Barriers to trade are a negative function of trade costs, transport costs, and tariffs.

Bergstrand (1989) also included per capita income, which is an indicator of demand sophistication (demand for luxury versus necessity goods), and incorporated factor endowment variables in the spirit of Heckscher-Ohlin and taste variables in the spirit of Linder:

$$
P X_{i j}=\Psi_{0}\left(Y_{i}\right)^{\Psi_{1}}\left(Y_{i} / L_{i}\right)^{\Psi_{2}}\left(Y_{j}\right)^{\Psi_{3}}\left(Y_{j} / L_{j}\right)^{\Psi_{4}}\left(D_{i j}\right)^{\Psi_{5}}\left(A_{i j}\right)^{\Psi_{6}} e_{i j}
$$

where $P X_{i j}$ represents flows from country $i$ to country $j, \beta_{0}$ is the intercept, $Y_{i}$ and $Y_{j}$ are the GDP of country $i$ and $j$ respectively, $\left(Y_{i} / L_{i}\right)$ and $\left(Y_{j} / L_{j}\right)$ stand for GDP per capita of country $i$ and $\boldsymbol{j}$ respectively, $\mathrm{D}_{\mathrm{ij}}$ represents the geographical distance between the economic centres of two partners, $\mathrm{A}_{\mathrm{ij}}$ factors aiding (e.g., common language and historical bonds) or representing a barrier to trade between partners.

The gravity model has been widely used in the applied literature to evaluate the impact of regional agreements (see Frankel, 1997; Carrère, 2006; Rault, Sova and Sova, 2008, Caporale et al., 2008), the border effect on trade flows (Anderson and Van Wincoop, 2003), and to simulate trade potential (Baldwin, 1994; Peridy, 2005a). 


\section{Econometric analysis}

\subsection{Methodological issues}

The gravity model is the theoretical underpinning of the econometric framework we adopt. As heterogeneity plays an important role in bilateral flows, individual fixed effects are introduced into the empirical model to take it into account. One can also examine the evolution over time of countries' behaviour through temporal fixed effects (economic or political events).

Most studies estimating a gravity model apply the ordinary least square (OLS) method to cross-section data. Several papers have argued that standard cross-section methods lead to biased results because they do not take into account heterogeneity (e.g., historical, cultural and linguistic factors). Panel data methods are therefore preferable as they enable one to control for specific effects (such as fixed or random effects), and hence eliminate the potential endogeneity bias resulting from unobserved individual heterogeneity.

Matyas (1997) stresses that the cross-section approach is affected by misspecification and suggests that the gravity model should be specified as a "three-way model" with exporter, importer and time effects (random or fixed ones). Egger and Pfaffermayr (2003) underline that the omission of specific effects for country pairs can bias the estimated coefficients. An alternative solution is to use an estimator to control bilateral specific effects as in a fixed effect model (FEM) or in a random effect model (REM). The advantage of the former is that it allows for unobserved or misspecified factors that simultaneously explain the trade volume between two countries and lead to unbiased and efficient results.

Plümper and Troeger (2004) have proposed a more efficient method called "the fixed effect vector decomposition (FEVD)" to accommodate time-invariant variables. Using Monte Carlo simulations, they compared the performances of the FEVD method to some other existing techniques, such as the fixed effect, or random effect, or the Hausman-Taylor methods. Their results indicate that the most reliable technique for small samples is FEVD if time-invariant variables are present and the other variables are correlated with specific effects, which is likely to be the case in our study.

In addition to FEM, REM, and FEVD, that are static panel data methods, we also use the Generalized Method of Moments (GMM) for dynamic panels of Arellano and Bover (1995) and Blundel and Bond (1998). This involves estimating a system containing both firstdifferenced and levels equations, providing a solution to problems such as simultaneity bias, 
inverse causality and omitted variables. Besides, this method controls for individual specific and time effects overcomes endogeneity bias. The model is well specified if the estimator is consistent (based on the Arellano-Bond AR(2) test) and the instruments are valid on the basis of Hansen's over-identification test.

\subsection{Econometric results}

Our aim is to analyse the trade specialisation dynamics of the EEC-2 vis-a-vis the EU15 using a gravity model. In particular, we want to investigate whether there has been an increase in intra-industry trade leading to economic convergence and to explain the trend of the share of intra-industry trade in total trade (inter- and intra-industry) between the EEC-2 and the EU-15. Following the new trade theory (Helpman, 1987, Hummels and Levinsohn, 1995), we estimate a trade equation for bilateral exports where differences in relative factor endowment $\left(\mathrm{DGDPT}_{\mathrm{ij}}\right)$ and relative country size $\left(\mathrm{RCS}_{\mathrm{ij}}\right)$ are the main determinants of the trends in the share of intra-industry specialisation. The bigger the difference between the partners' factor endowments, the lower the share of the intra-industry trade will be. The larger the measure of relative country size is, the higher the share of intra-industry trade. Helpman (1987) in fact found a positive correlation between the share of intra-industry trade and a relative country size (interpreted as empirical support for the theory of returns to scale and imperfect competition in international trade), and a negative correlation with differences in relative factor endowments. After estimating the model over the whole sample, we also consider two subsamples in order to detect any sizeable changes in the share of intra-industry trade.

\section{Model Specification}

We model bilateral exports as a function of GDP, the difference in per capita income, relative country size and geographic distance. The equation is the following:

$$
X_{i j t}=e^{a_{0}} G D P_{i t}^{a_{1}} G D P_{j t}^{a_{2}} \operatorname{DGDPT}_{i j t}^{a_{3}} \operatorname{Dist}_{i j}^{a_{4}} \operatorname{RCS}_{i j t}^{a_{5}} \operatorname{Acc}_{i j t}^{a_{6}} e^{u_{i j}} e^{v_{t}} e^{\varepsilon_{i j t}}
$$

where: $\mathrm{X}_{\mathrm{ij}}$ denotes bilateral trade between countries $\boldsymbol{i}$ and $\boldsymbol{j}$ at time $\boldsymbol{t}$ with $\mathrm{i} \# \mathrm{j}$

$\mathrm{a}_{\mathrm{o}}$ is the intercept;

- $\mathrm{GDP}_{\mathrm{it}}, \mathrm{GDP}_{\mathrm{jt}}$ stand for Gross Domestic Product of country $\boldsymbol{i}$ and country $\boldsymbol{j}$ (expected sign: positive)

- $\mathrm{RCS}_{\mathrm{ij}}$ is relative country size defined as follows (expected sign: positive): 
- $R C S_{i j t}^{(+)}=\left[1-\left(\frac{G D P_{i t}}{G D P_{i t}+G D P_{j t}}\right)^{2}-\left(\frac{G D P_{j t}}{G D P_{i t}+G D P_{j t}}\right)^{2}\right]$

and $0<\log \operatorname{RCS}>0.5$. The higher its value is, the higher the share of intra-industry trade.

- DGDPT $_{\mathrm{ijt}}$ is the difference in GDP per capita between partners and is a proxy for economic distance or comparative advantage intensity ${ }^{8}$ (expected sign: positive for inter- and negative for intra-industry trade)

- Dist $\mathrm{ij}_{\mathrm{j}}$ represents the geographical distance between two countries (expected sign: negative)

- Acc $_{\mathrm{ijt}}$ is a dummy variable that equals 1 if country $\boldsymbol{i}$ and country $\boldsymbol{j}$ have signed a regional agreement, and zero otherwise (a positive correlation between this variable and intra-industry trade is expected)

- $\varepsilon_{\mathrm{ijt}}$ is the error term,

- $\mathrm{u}_{\mathrm{ij}}$ is bilateral effects

- $v_{\mathrm{t}}$ is time effects

After log-linearisation, equation (9) becomes the following in a static context:

$\log \left(X_{i j t}\right)=a_{0}+a_{1} \log \left(G D P_{i t}\right)+a_{2} \log \left(G D P_{j t}\right)+a_{3} \log \left(D G D P T_{i j t}\right)+a_{4} \log \left(D_{i s t_{i j}}\right)+$

$+a_{5} \log \left(R C S_{i j t}\right)+a_{6} A C C_{i j t}+u_{i j}+v_{t}+\varepsilon_{i j t}$

or, in a dynamic context:

$\log \left(X_{i j t}\right)=a_{0}+a_{1} \log \left(X_{i j t-1}\right)+a_{2} \log \left(G D P_{i t}\right)+a_{3} \log \left(G D P_{j t}\right)+a_{4} \log \left(D G D P T_{i j t}\right)+$ $a_{5} \log \left(\right.$ Dist $\left._{i j}\right)+a_{6} \log \left(R C S_{i j t}\right)+a_{7} A_{c C_{i j t}}+v_{t}+\varepsilon_{i j t}$

Our panel includes the EEC-2 and the EU-15 countries ${ }^{9}$. The data are annual, and the sample period is 1990 - 2006. The model is estimated over the whole period, and also for two subperiods (1990-1999 and 2000-2006). As a robustness check, we use all the estimation methods previously outlined.

\footnotetext{
${ }^{8}$ Note that when we use GDP per capita in our estimates, we find a strong correlation between GDP of the exporting country and their GDP per capita. Consequently, we have decided to use the difference in GDP per capita between partners as a regressor.

9 EU-15: Austria, Belgium, Luxemburg, Denmark, England, Finland, France, Germany, Greece, Holland, Ireland, Italy, Portugal, Spain, Sweden.
} 


\section{Results}

The estimation results using REM, FEM and FEVD are reported in Table 6a and those using GMM and Table 6b. The results based on FEVD and FEM are similar, which indicates robustness of our estimates, and highlight the effects of the time-invariant variables on trade flows. For our static panel data analysis, FEVD is more appropriate given the sample size, and has a higher $\mathrm{R}^{2}$, equal to 0.90 (see Table 6a).

In all cases, the variables are significant and have the expected sign, consistent with the gravity model. Access to a larger market increases trade volume. On the contrary, the distance variable (a proxy for transportation costs) reduces trade. Its elasticity is systematically high, indicating that trade flows are extremely sensitive to transportation costs.

The analysis of how specialisation has changed over time shows a shift towards intraindustry trade in the second period (see columns (6) and (9)). Owing to differences in factor endowments and relative country size inter-industry trade dominates in the first period, which was a transition period with significant economic changes and adjustments. By contrast, in the second period the negative effect of DGDPT $_{\mathrm{ijt}}$ drives up the share of intra-industry trade (IIT). This is negatively related to economic distance and positively related to relative country size. The period from 2000 is characterised by an increasing role of multinational firms in the markets of both countries and a higher growth rate.

The GMM estimates (see Table 6b) appear to be consistent, there is no residual autocorrelation, and the validity of the instruments is confirmed by Hansen's test. The coefficients are all statistically significant and with the expected signs. Splitting the sample highlights the shift towards intra-industry trade which has occurred in the second period.

The increase of intra-industry trade is due to generally higher trade flows between the EEC-2 and EU-15 but also to the presence of vertically integrated multinational firms. Hoekman and Djankov (1996) report that higher FDI is behind increasing vertical intra industry trade between CEEC and EU countries. In the literature, a high share of intraindustry trade is often associated to deeper economic integration between countries. Kaitila (1999) found that intra-industry trade between the transition countries and the core EU is low compared to intra-industry trade within the EU, but has increased as a result of trade pattern changes.

It is possible that the estimated share for intra-industry trade reflects vertical intraindustry trade resulting from the strategy of multinationals splitting their production process across countries. To shed light on this issue, it is necessary to analyse the imports of intermediate goods and equipment used by foreign firms for the production of final goods, 
which are then exported. During the period under investigation in Bulgaria and Romania there was an increase of imports of intermediate goods and equipment, especially after 2000; these exceeded $50 \%$ of total imports to the EU-15.

We are interested in establishing whether imports of intermediate goods affected exports of both countries to the EU-15: a positive impact would indicate the existence of intraindustry trade based on the international division of labour, reflecting vertical integration pursued by multinational firms, and thus interdependence between the EEC-2 and EU-15. For this purpose, we estimate a trade equation including a control variable, i.e. imports of intermediate goods and equipment, using the same dataset as before. The specification is the following:

in a static context:

$$
\begin{aligned}
& \log \left(X_{i j t}\right)=a_{0}+a_{1} \log \left(G D P_{i t}\right)+a_{2} \log \left(G D P_{j t}\right)+a_{3} \log \left(D G D P T_{i j t}\right)+a_{4} \log \left(\text { Dist }_{i j}\right)+ \\
& +a_{5} \log \left(M \text { int }_{i j t}\right)+a_{6} \log \left(R C S_{i j t}\right)+a_{7} A c c_{i j t}+u_{i j}+v_{t}+\varepsilon_{i j t}
\end{aligned}
$$

in a dynamic context:

$$
\begin{aligned}
& \log \left(X_{i j t}\right)=a_{0}+a_{1} \log \left(X_{i j t-1}\right)+a_{2} \log \left(G D P_{i t}\right)+a_{3} \log \left(G D P_{j t}\right)+a_{4} \log \left(D G D P T_{i j t}\right)+ \\
& +a_{5} \log \left(D_{i s t_{i j}}\right)++a_{6} \log \left(M \text { int }_{i j t}\right)+a_{7} \log \left(R C S_{i j t}\right)+a_{8} A c c_{i j t}+v_{t}+\varepsilon_{i j t}
\end{aligned}
$$

where: Mint $_{\mathrm{ijt}}=$ imports of intermediate goods and equipment of country $\boldsymbol{i}$ from country $\boldsymbol{j}$,

$$
\mathrm{X}_{\mathrm{ijt}}=\text { exports of country } \boldsymbol{i} \text { towards the country } \boldsymbol{j} \text {, }
$$

The other variables are defined as before.

The results can be summarised as follows. The positive sign of the coefficient on the control variable confirms the existence of trade flows based on the international division of the production process of multinational firms of the EU-15, i.e. of vertical intra-industry trade (see Table 7). An example is the increase of Romanian and Bulgarian textile exports. The EEC-2 import quality intermediate goods from the EU-15; these are then used by foreign firms together with cheap labour for the production of final products, which are exported to the EU-15. ${ }^{10}$ Essentially, one observes a strategy of vertical division of labour, based on the comparative advantage the EEC-2 have in labour-intensive production segments and their comparative disadvantage in capital-intensive sectors. Overall, it appears that vertical intraindustry trade dominates and largely accounts for the increase in trade flows with the EU-15.

\footnotetext{
${ }^{10}$ In 2005, hourly labour costs were equal to 2.33 euros in Romania, 1.55 in Bulgaria and 25.1 in the EU-15 (source: Eurostat).
} 
Our finding of vertical intra-industry trade in the second period is consistent with previous evidence (see Kaitila, 1999). Aturupane et al. (1999), Kaitila and Widgren (1999) and Fidrmuc and Djablík (2003) report that for the CEEC the most important component of intra-industry trade is of the vertical type. Caetano and Galego (2006) found a significant decline in inter-industry trade and an increasing specialisation in vertical IIT. However, the risk for countries such as Bulgaria and Romania with labour-intensive sectors is that the development of inter-industry and vertical intra-industry trade will perpetuate trade specialisation based on the exploitation of low wages.

\section{Conclusions}

In this paper, we have investigated trade specialisation of the EEC-2 vis-à-vis the EU15 over the period 1990-2006 using both static and dynamic panel data techniques which take into account heterogeneity and hence avoid biased estimates. Specifically, we have examined whether there has been a shift towards intra-industry trade, necessary for economic convergence and technological catch-up. Our empirical findings can be summarised as follows.

Trade volumes (both exports and imports) have increased significantly since the signing in 1993 of the European Agreement with the EU. In 2000, the volume of trade with the EU-15 was similar to the volume of intra-European trade, indicating trade integration. In general, exports are dominated by products with labour-intensive comparative advantages. In the period 2000-2006, there was an increase (more for Romania than for Bulgaria) of exports of products with higher value added, incorporating physical capital and skilled labour, but no significant changes in competitiveness such as to improve the trade balance.

Our results indicate a shift towards intra-industry trade, specifically of the vertical type: EU multinational firms manufacture products in Romania and Bulgaria exploiting the comparative advantage of low labour costs and then export them. This type of trade increases production and labour productivity, but does not lead to economic convergence, which is associated instead to horizontal intra-industry trade, i.e. to simultaneous export and import flows of comparable size of products with similar quality, technology and value added. In other words, in the context of European integration, the EEC-2 have followed the strategy of exploiting their comparative advantage of low labour costs in the context of the international division of production processes, although some sectors with high value added (e.g., electric and mechanics) have also expanded (similar results were reported by Andreff (1998) for other 
Eastern European economies as well). Therefore, the challenge for Romania and Bulgaria is to change their production patterns from complementary to competitive and move towards international market segments with high quality and high value-added products, thereby accelerating convergence towards the EU-15. 


\section{References}

[1] Albu L. Trends in structural changes and convergence in EU. Romanian Journal of Economic Forecasting $2008 ;(1) ; 91-101$

[2] Anderson J E. A theoretical foundation for the gravity equation. American Economic Review 1979; 69(1); 106-16

[3] Anderson J E, Van Wincoop E. Gravity with gravitas: a solution to the border effect puzzle. American Economic Review 2003 ; 93(1) ; 170-192

[4] Andreff M La spécialisation du commerce entre l'Union européenne et les pays d'Europe centrale et orientale : quelle évolution ?. Revue d'études comparatives EST/OUEST 1998; 29(4); 161-189

[5] Arellano M, Bond S. Some Tests of Specification for Panel Data: Monte Carlo Evidence and an Application to Employment Equation. Review of Economic Studies 1991;58;277-297.

[6] Arellano M, Bover O. Another Look at the instrumental variables Estimation of ErrorComponent Models. Journal of Econometric1995; 68; 29-51

[7] Aturupane C, Djankov S, Hoekman B. Horizontal and Vertical Intra-Industry Trade between Eastern Europe and the European Union. Weltwirtschaftliches Archiv Kiel 1999; $135(1) ; 63-81$

[8] Balassa B. Trade Liberalisation and 'Revealed' Comparative Advantage. Manchester School of Economics and Social Studies 1965; 33; 99-123

[9] Balassa B. Tariff Reductions and Trade in Manufactures among the Industrial Countries. American Economic Review 1966;56;466-473

[10] Baldwin R. Towards an integrated Europe, CEPR London 1994

[11] Bergstrand J H. The generalized gravity equation, monopolistic competition, and the factor-proportions theory in international trade. Review of Economics and Statistics 1989; 71(1); 143-53

[12] Bergstrand $\mathrm{J} \mathrm{H}$. The gravity equation in international trade: some microeconomic foundations and empirical evidence. Review of Economics and Statistics 1985; 67(3); 474-81

[13] Blundel R, Bond S. Initial Contitions and Moment Restrictions in Dinamic Panel Data Models. Journal of Econometrica 1998; 87(1); 115-143-1998.

[14] Brülhart M. Marginal Intra-Industry Trade: Meassurement and the Relevance for the Pattern of Industrial Adjustement. Weltwirtschaftliches Archiv 1994;130(3);600-613

[15] Caetano J, Galego A In Search for Determinants of intra-industry trade within an Enlarged Europe. Working paper 2006/02. 
[16] Caporale G.M., Rault C., Sova R., Sova A. On the bilateral trade effects of free trade agreements between the UE-15 and the CEEC - 4 countries. Forthcoming in Review of World Economics, 2008.

[17] Carrere C. Revisiting the Effects of Regional Trading Agreements on Trade Flows with Proper Specification of Gravity Model. European Economic Review 2006 vol. 50; 223-247

[ 18] Cavallaro E' Mulino M. Vertical Innovation and Catching-Up: Implications of EU Integration for CEECs-5. International Advances in Economic Research 2008 ;(14);265-279 [19] Egger P, Pfaffermayr M. The proper panel econometric specification of the gravity equation: a three-way model with bilateral interaction effects. Empirical Economics 2003; 28; $571-580$

[20] Eichengreen B, Irwin D A. Trade blocs, currency blocs and the reorientation of world trade in the 1930s. Journal of International Economics Elsevier 1995;38(1-2);1-24

[21] Fidrmuc J, Djablík M. Intra-industry Trade between the EU and the CEECs The Importance of FDI in Trade Structure.. East - West Conference 2003

[22] Fontagne L, Freudenberg M. Intra-Industry Trade: Methodological Issues Reconsidered Working Papers CEPII Research Center 1997; 01

[23] Frankel J. Regional trading blocs in the world economic system. Institute for International Economics Washington 1997

[24] Grubel H G, Lloyd P J. Intra-industry trade: the theory and measurement of international trade in differencial products. Macmillan London 1975;

[25] Helpman E, Krugman P R. Market Structure and Foreign Trade: Increasing Returns, Imperfect Competition, and the International Economy. Cambridge/Mass.: MIT Press, 1985

[26] Helpman E. Imperfect Competition and International Trade: Evidence from Fourteen Industrial Countries. Journal of the Japanese and International Economies 1987; 1; 62-81

[27 ] Hoeckman B, Djankov S. Intra-Industry Trade, Foreign Direct Investment and the Reorientation of East European Exports. CEPR London Discussion Paper 1996;1377

[28] Hummels D, Levinsohn J. Monopolistic Competition and International Trade: Reconsidering the Evidence Quarterly Journal of Economics 1995; 110; 798-836

[29] Iancu A. Real Convergence and Integration. Romanian Journal of Economic Forecasting $2008 ;(1) ; 27-40$

[30] Kaitila V. Trade and Revealed Comparative Advantage: Hungary, the Czech Republic, and the European Union. BOFIT Discussion Papers 1999(8) 
[31] Kaitila V, Widgren M. Revealed Comparative Advantage in Trade between the European Union and the Baltic Countries. The Research Institute of the Finnish Economy Discussion Papers 1999; 697

[32] Lafay G. La mesure des avantages comparatifs révélés. Économie prospective internationale 1990;41

[33] Linnemann H. An econometric Study of International Trade Flows. North Holland, Amsterdam 1966

[34] Lundberg L.Economic Integration, Inter- and Intra-industry Trade: the Case of Sweden and the EC. Scandinavian Journal of Economics 1992; 94(3); 393-408

[35] Matyas L. Proper Econometric Specification of the Gravity Model. The World Economy $199720(3) ; 363-368$

[36] Péridy N. Towards a New Trade Policy Between the USA and Middle-East Countries: Estimating Trade Resistance and Export Potential. World Economy 2005; 28(4); 491-518

[37] Plumper T, Troeger V E. The Estimation of Time-Invariant Variables in Panel Analysis with Unit Fixed Effects. Konstanz University, mimeo, 2004

[38] Pöyhönen P. A Tentative Model for the Volume of Trade between Countries, Welwirtschftliches Archiv, 1963; 90(1); 93-99

[39] Rault C, Sova R, Sova A. Modeling international trade flows between CEEC and OECD countries. Forthcoming in Applied Economics Letters. 2008

[40] Ruffin,R The nature and Significance of Intra-industry Trade. Economic and Financial Review 1999;2-9.

[41] Thom R, McDowell M. Measuring Marginal Intra-Industry Trade. Welwirtschftliches Archiv 1999;135(1);48-61

[42] Tinbergen J. Shaping the World Economy: Suggestions for an International Economic Policy. The Twentieth Century Fund New York 1962. 
Figure 1: Exports, imports and trade balance of Romania and Bulgaria

(in million dollars) $1990 \rightarrow 2006$

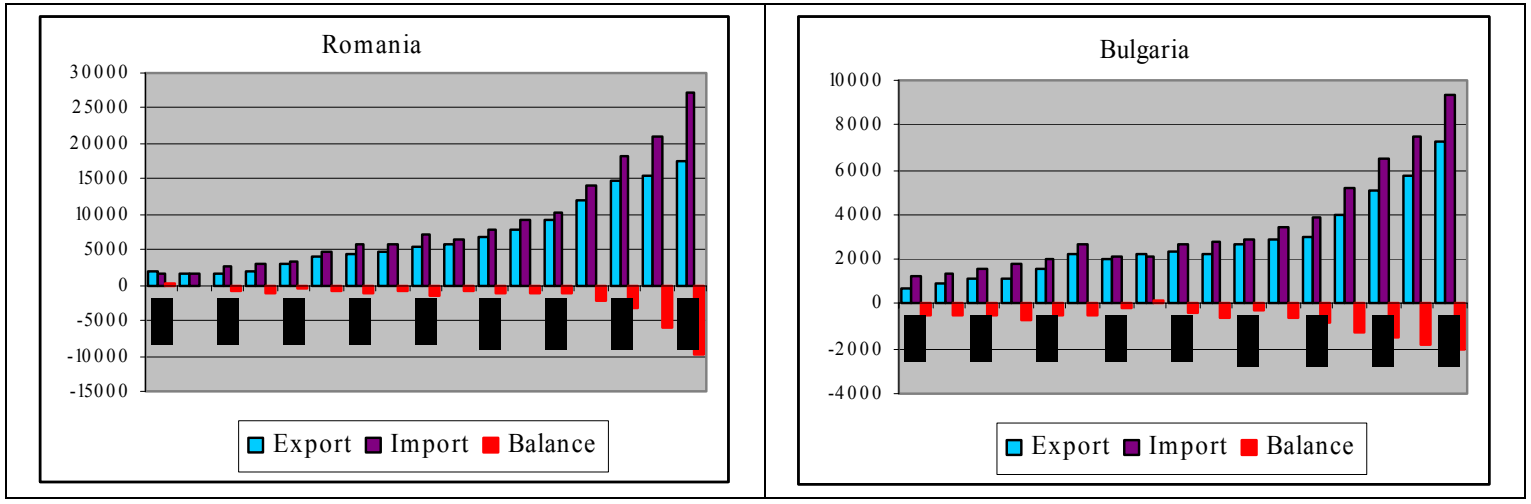

Source: Our calculations using the CHELEM - CEPII database

Figure 2: Exports of Romania and Bulgaria by sector (in \%)

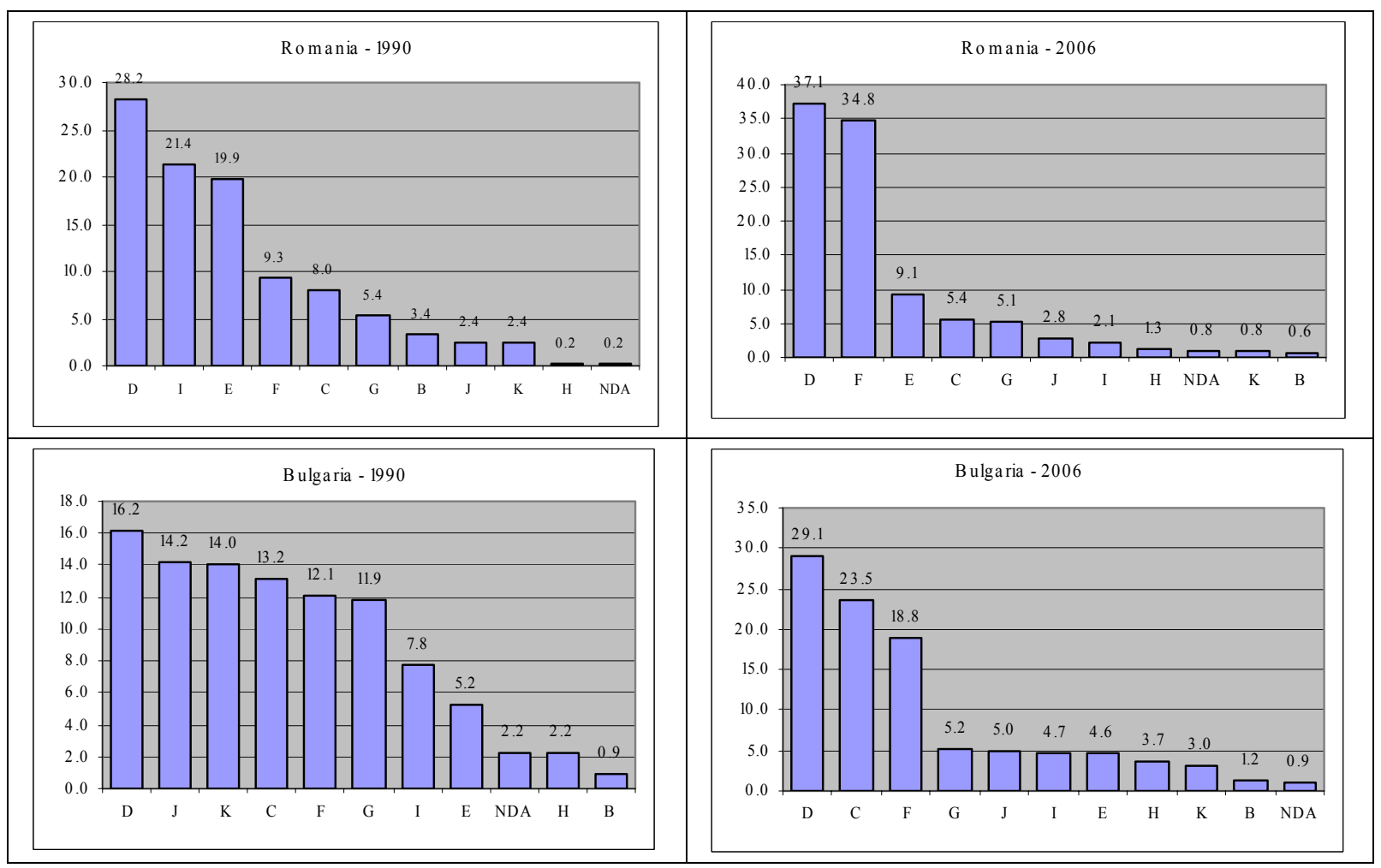

Source: Our calculations using the CHELEM - CEPII database 
Figure 3: Imports of Romania and Bulgaria by sector (in \%)

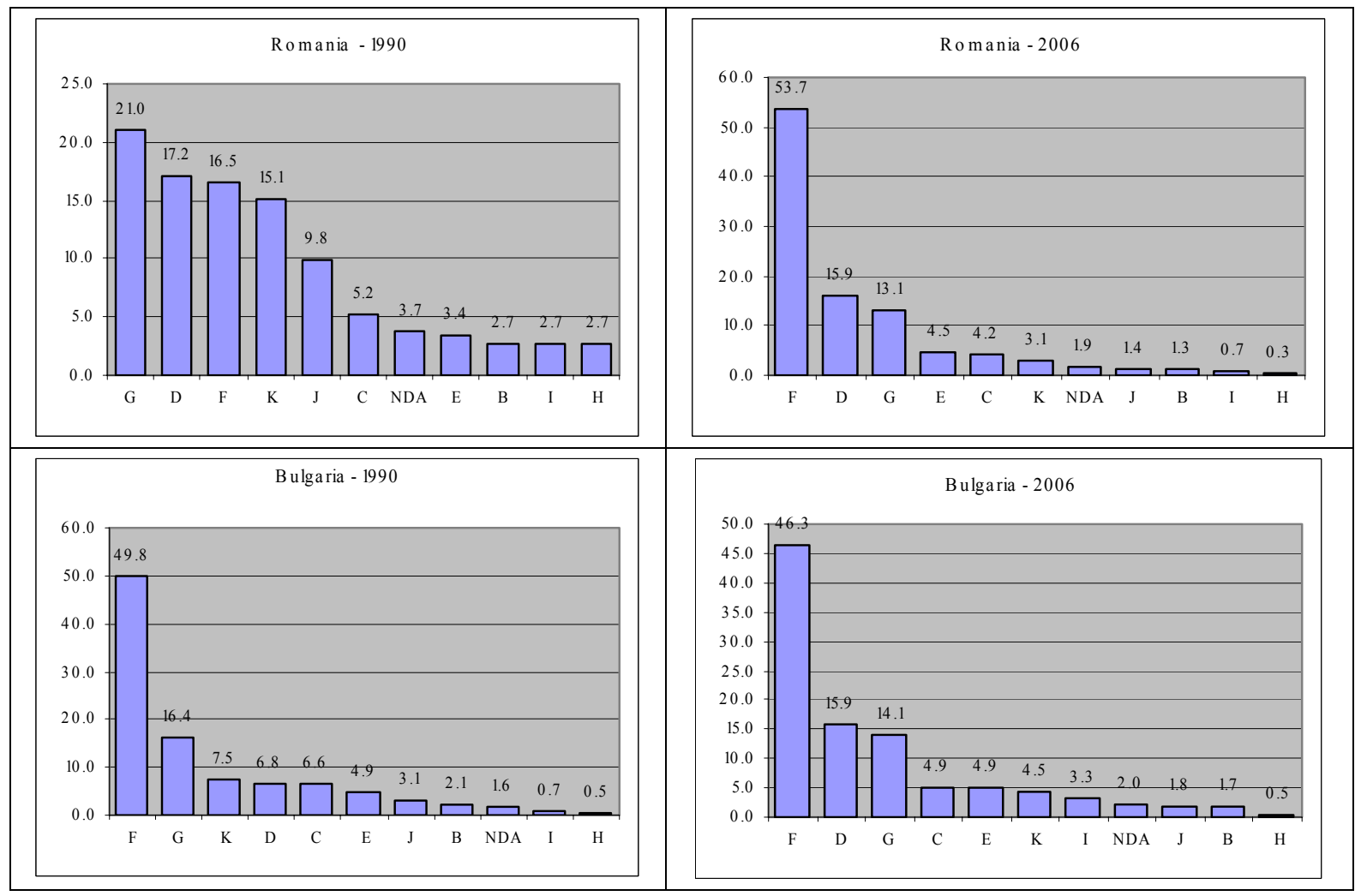

Source: Our calculations using the CHELEM - CEPII database 
Table 1: Country and sector codes

\begin{tabular}{|l|l|l||c|l|l|}
\hline \multirow{2}{*}{ No } & \multicolumn{2}{|c||}{ Country } & \multirow{2}{*}{ No } & \multicolumn{2}{c|}{ Sector } \\
\cline { 2 - 3 } & Code & Name & & Code & Products \\
\hline \hline 1 & AUT & Austria & 1 & B & Building materials \\
\hline 2 & DEU & Germany & 2 & C & Iron and steel industry \\
\hline 3 & DNK & Denmark & 3 & D & Textiles, leathers \\
\hline 4 & ESP & Spain & 4 & E & Woods and paper \\
\hline 5 & FIN & Finland & 5 & F & Electric and mechanics \\
\hline 6 & FRA & France & 6 & G & Chemicals \\
\hline 7 & GBR & United Kingdom & 7 & H & Minerals \\
\hline 8 & GRC & Greece & 8 & I & Energy \\
\hline 9 & IRL & Ireland & 9 & J & Agriculture \\
\hline 10 & ITA & Italy & 10 & K & Food \\
\hline 11 & NDL & Netherlands & 11 & NDA & N.D.A. \\
\hline 12 & PRT & Portugal & & & \\
\hline 13 & SWE & Sweden & & & \\
\hline 14 & UEBL & Belgium- Luxembourg & & & \\
\hline
\end{tabular}

Table 2: Revealed comparative advantages (Lafay indicator $\mathbf{-} 2$ digit level)

\begin{tabular}{|c|c|c|c|c|c|c|c|c|c|c|}
\hline \multirow[b]{2}{*}{ Sector } & \multicolumn{5}{|c|}{ Romania } & \multicolumn{5}{|c|}{ Bulgaria } \\
\hline & 1990 & 1995 & 2000 & 2004 & 2006 & 1990 & 1995 & 2000 & 2004 & 2006 \\
\hline B & 0.07 & 0.43 & 0.11 & -0.47 & -0.74 & -0.20 & -0.06 & -0.31 & -0.54 & -0.77 \\
\hline $\mathrm{C}$ & 0.34 & 4.75 & 3.23 & 3.10 & 1.43 & 1.14 & 12.42 & 14.68 & 17.81 & 26.48 \\
\hline D & 1.20 & 4.60 & 10.28 & 19.71 & 24.63 & 1.63 & 4.11 & 6.48 & 14.67 & 18.80 \\
\hline $\mathbf{E}$ & 1.80 & 1.55 & 2.20 & 4.90 & 5.29 & 0.06 & -1.91 & -1.80 & 0.27 & -0.35 \\
\hline $\mathbf{F}$ & -0.78 & -7.65 & -11.72 & -19.55 & -21.88 & -6.56 & -15.52 & -14.44 & -27.09 & -39.16 \\
\hline $\mathbf{G}$ & -1.70 & -1.55 & -3.80 & -8.27 & -9.35 & -0.79 & -0.77 & -4.43 & -9.02 & -12.62 \\
\hline H & -0.27 & 0.00 & 0.66 & 0.64 & 1.22 & 0.29 & 1.28 & 1.06 & 2.29 & 4.64 \\
\hline I & 2.03 & -0.29 & -0.51 & 1.97 & 1.65 & 1.23 & 0.07 & 0.30 & 1.79 & 1.96 \\
\hline $\mathbf{J}$ & -0.81 & 0.20 & 1.18 & 1.63 & 1.66 & 1.94 & 1.04 & 0.37 & 2.69 & 4.60 \\
\hline $\mathbf{K}$ & -1.50 & -1.49 & -0.86 & -2.05 & -2.67 & 1.13 & -0.55 & -0.88 & -0.81 & -2.02 \\
\hline NDA & -0.39 & -0.56 & -0.77 & -1.61 & -1.24 & 0.11 & -0.12 & -1.02 & -2.06 & -1.56 \\
\hline
\end{tabular}

Source: Our calculations using the CHELEM - CEPII database

Table 3 (a): Grubel-Lloyd indicator for the main sectors (2-digit level)

\begin{tabular}{|c||r|r|r|r|r||r|r|r|r|r|}
\hline \multicolumn{1}{|c||}{} & \multicolumn{9}{|c||}{ Romania } & \multicolumn{6}{c|}{ Bulgaria } \\
\cline { 2 - 12 } Sector & $\mathbf{1 9 9 0}$ & $\mathbf{1 9 9 5}$ & $\mathbf{2 0 0 0}$ & $\mathbf{2 0 0 4}$ & $\mathbf{2 0 0 6}$ & $\mathbf{1 9 9 0}$ & $\mathbf{1 9 9 5}$ & $\mathbf{2 0 0 0}$ & $\mathbf{2 0 0 4}$ & $\mathbf{2 0 0 6}$ \\
\hline \hline B & 0.84 & 0.73 & 1.00 & 0.69 & 0.48 & 0.41 & 0.88 & 0.73 & 0.67 & 0.70 \\
\hline C & 0.71 & 0.25 & 0.46 & 0.74 & 0.91 & 0.94 & 0.20 & 0.23 & 0.38 & 0.42 \\
\hline D & 0.99 & 0.99 & 0.97 & 0.89 & 0.80 & 1.00 & 0.99 & 0.98 & 0.94 & 0.83 \\
\hline E & 0.26 & 0.78 & 0.77 & 0.74 & 0.88 & 0.76 & 0.62 & 0.69 & 0.89 & 0.85 \\
\hline F & 0.81 & 0.44 & 0.59 & 0.63 & 0.59 & 0.25 & 0.35 & 0.48 & 0.47 & 0.48 \\
\hline G & 0.48 & 0.65 & 0.46 & 0.42 & 0.39 & 0.60 & 0.88 & 0.65 & 0.46 & 0.44 \\
\hline H & 0.16 & 0.93 & 0.53 & 0.51 & 0.46 & 0.59 & 0.33 & 0.51 & 0.26 & 0.28 \\
\hline I & 0.20 & 0.73 & 0.43 & 0.35 & 0.69 & 0.27 & 0.95 & 0.94 & 0.79 & 0.95 \\
\hline J & 0.43 & 0.82 & 0.59 & 0.69 & 0.87 & 0.55 & 0.79 & 0.93 & 0.70 & 0.63 \\
\hline K & 0.18 & 0.29 & 0.42 & 0.35 & 0.27 & 0.97 & 0.79 & 0.79 & 0.78 & 0.69 \\
\hline NDA & 0.11 & 0.40 & 0.32 & 0.19 & 0.44 & 0.90 & 0.82 & 0.48 & 0.32 & 0.53 \\
\hline
\end{tabular}

Source: Our calculations using the CHELEM - CEPII database 
Table 3(b) : Grubel-Lloyd indicator with the main partners (2-digit level)

\begin{tabular}{|c|c|c|c|c|c|c|c|c|c|c|}
\hline \multirow[b]{2}{*}{ Country } & \multicolumn{5}{|c|}{ Romania } & \multicolumn{5}{|c|}{ Bulgaria } \\
\hline & 1990 & 1995 & 2000 & 2004 & 2006 & 1990 & 1995 & 2000 & 2004 & 2006 \\
\hline AUT & 0.67 & 0.71 & 0.77 & 0.71 & 0.57 & 0.53 & 0.56 & 0.48 & 0.60 & 0.68 \\
\hline DEU & 0.96 & 0.88 & 0.89 & 0.81 & 0.73 & 0.63 & 0.72 & 0.78 & 0.74 & 0.76 \\
\hline DNK & 0.43 & 0.43 & 0.72 & 0.63 & 0.56 & 0.42 & 0.76 & 0.81 & 0.69 & 0.61 \\
\hline ESP & 0.49 & 0.80 & 0.87 & 0.97 & 0.87 & 0.67 & 0.39 & 0.91 & 0.87 & 0.75 \\
\hline FIN & 0.64 & 0.72 & 0.55 & 0.99 & 0.61 & 0.98 & 0.46 & 0.50 & 0.76 & 0.99 \\
\hline FRA & 0.85 & 0.93 & 1.00 & 0.94 & 0.86 & 0.79 & 0.96 & 0.92 & 1.00 & 0.89 \\
\hline GBR & 0.73 & 0.85 & 0.87 & 0.90 & 0.90 & 0.74 & 0.94 & 0.86 & 0.93 & 0.89 \\
\hline GRC & 0.95 & 0.80 & 0.84 & 0.90 & 0.88 & 0.70 & 0.99 & 0.89 & 0.70 & 0.81 \\
\hline ITA & 0.57 & 0.99 & 0.95 & 0.94 & 0.84 & 0.69 & 0.97 & 0.93 & 0.98 & 0.87 \\
\hline NDL & 0.94 & 0.94 & 0.84 & 0.77 & 0.55 & 0.63 & 1.00 & 0.74 & 0.53 & 0.57 \\
\hline PRT & 0.98 & 0.60 & 0.65 & 0.89 & 0.48 & 0.81 & 0.48 & 0.99 & 0.67 & 0.51 \\
\hline SWE & 0.97 & 0.72 & 0.82 & 0.62 & 0.59 & 0.58 & 0.49 & 0.63 & 0.62 & 0.57 \\
\hline UEBL & 0.76 & 0.97 & 0.97 & 0.99 & 0.69 & 0.65 & 0.94 & 0.41 & 0.58 & 0.53 \\
\hline
\end{tabular}

Source: Our calculations using the CHELEM - CEPII database

Table 4 (a): Trade flows between EEC-2 and EU-15 by partner (2-digit level)

\begin{tabular}{|l||c|c|c|c||c|c|c|c|}
\hline \multirow{2}{*}{ 1990-2006 } & \multicolumn{9}{c||}{ Romania } & \multicolumn{4}{c|}{ Bulgaria } \\
\cline { 2 - 10 } & IIT & HIIT & VIIT & IT & IIT & HIIT & VIIT & IT \\
\hline \hline \multirow{2}{*}{ AUT } & 0.57 & 0.04 & 0.53 & 0.43 & 0.71 & 0.04 & 0.67 & 0.29 \\
\hline DEU & 0.71 & 0.22 & 0.48 & 0.29 & 0.78 & 0.20 & 0.58 & 0.22 \\
\hline DNK & 0.59 & 0.00 & 0.59 & 0.41 & 0.63 & 0.00 & 0.63 & 0.37 \\
\hline ESP & 0.82 & 0.03 & 0.79 & 0.18 & 0.76 & 0.04 & 0.72 & 0.24 \\
\hline FIN & 0.55 & 0.00 & 0.55 & 0.45 & 0.98 & 0.01 & 0.97 & 0.02 \\
\hline FRA & 0.82 & 0.09 & 0.73 & 0.18 & 0.96 & 0.08 & 0.88 & 0.04 \\
\hline GBR & 0.86 & 0.05 & 0.81 & 0.14 & 0.90 & 0.04 & 0.86 & 0.10 \\
\hline GRC & 0.86 & 0.03 & 0.84 & 0.14 & 0.79 & 0.11 & 0.68 & 0.21 \\
\hline IRL & 0.00 & 0.00 & 0.00 & 1.00 & 0.00 & 0.00 & 0.00 & 1.00 \\
\hline ITA & 0.81 & 0.22 & 0.59 & 0.19 & 0.89 & 0.19 & 0.70 & 0.11 \\
\hline NDL & 0.51 & 0.02 & 0.49 & 0.49 & 0.55 & 0.02 & 0.53 & 0.45 \\
\hline PRT & 0.45 & 0.00 & 0.45 & 0.55 & 0.42 & 0.00 & 0.41 & 0.58 \\
\hline SWE & 0.54 & 0.01 & 0.53 & 0.46 & 0.59 & 0.01 & 0.58 & 0.41 \\
\hline UEBL & 0.69 & 0.02 & 0.66 & 0.31 & 0.48 & 0.04 & 0.44 & 0.52 \\
\hline
\end{tabular}

Source: Our calculations using the CHELEM - CEPII database 
Table 4 (b): Trade flows between EEC-2 and EU-15 by sector (2-digit level)

\begin{tabular}{|c|c|c|c|c|c|c|c|c|}
\hline & \multicolumn{4}{|c|}{ Romania } & \multicolumn{4}{|c|}{ Bulgaria } \\
\hline 1990-1999 & IIT & HIIT & VIIT & IT & IIT & HIIT & VIIT & IT \\
\hline B & 0.86 & 0.16 & 0.70 & 0.14 & 0.77 & 0.25 & 0.52 & 0.23 \\
\hline $\mathrm{C}$ & 0.35 & 0.12 & 0.23 & 0.65 & 0.73 & 0.14 & 0.59 & 0.27 \\
\hline D & 0.86 & 0.09 & 0.77 & 0.14 & 0.70 & 0.07 & 0.63 & 0.30 \\
\hline $\mathbf{E}$ & 0.74 & 0.09 & 0.65 & 0.26 & 0.55 & 0.08 & 0.47 & 0.45 \\
\hline $\mathbf{F}$ & 0.55 & 0.02 & 0.53 & 0.45 & 0.29 & 0.01 & 0.28 & 0.71 \\
\hline $\mathbf{G}$ & 0.37 & 0.03 & 0.35 & 0.63 & 0.51 & 0.02 & 0.49 & 0.49 \\
\hline $\mathbf{H}$ & 0.03 & 0.01 & 0.02 & 0.97 & 0.56 & 0.04 & 0.52 & 0.44 \\
\hline I & 0.11 & 0.00 & 0.11 & 0.89 & 0.44 & 0.04 & 0.40 & 0.56 \\
\hline $\mathbf{J}$ & 0.29 & 0.10 & 0.19 & 0.71 & 0.92 & 0.05 & 0.87 & 0.08 \\
\hline $\mathbf{K}$ & 0.41 & 0.02 & 0.39 & 0.59 & 0.69 & 0.03 & 0.66 & 0.31 \\
\hline \multicolumn{9}{|l|}{$2000-2006$} \\
\hline B & 0.21 & 0.07 & 0.14 & 0.79 & 0.62 & 0.54 & 0.08 & 0.38 \\
\hline $\mathrm{C}$ & 0.60 & 0.20 & 0.40 & 0.40 & 0.67 & 0.18 & 0.50 & 0.33 \\
\hline D & 0.75 & 0.10 & 0.65 & 0.25 & 0.80 & 0.11 & 0.69 & 0.20 \\
\hline $\mathbf{E}$ & 0.94 & 0.10 & 0.83 & 0.06 & 0.76 & 0.10 & 0.66 & 0.24 \\
\hline $\mathbf{F}$ & 0.59 & 0.02 & 0.57 & 0.41 & 0.36 & 0.01 & 0.35 & 0.64 \\
\hline $\mathbf{G}$ & 0.37 & 0.04 & 0.33 & 0.63 & 0.23 & 0.02 & 0.21 & 0.77 \\
\hline H & 0.48 & 0.00 & 0.48 & 0.52 & 0.44 & 0.15 & 0.30 & 0.56 \\
\hline I & 0.39 & 0.06 & 0.33 & 0.61 & 0.60 & 0.04 & 0.55 & 0.40 \\
\hline $\mathbf{J}$ & 0.97 & 0.19 & 0.78 & 0.03 & 0.57 & 0.15 & 0.41 & 0.43 \\
\hline $\mathbf{K}$ & 0.23 & 0.03 & 0.21 & 0.77 & 0.55 & 0.05 & 0.50 & 0.45 \\
\hline \multicolumn{9}{|l|}{ 1990-2006 } \\
\hline B & 0.36 & 0.12 & 0.24 & 0.64 & 0.67 & 0.22 & 0.45 & 0.33 \\
\hline $\mathrm{C}$ & 0.86 & 0.29 & 0.57 & 0.14 & 0.60 & 0.17 & 0.44 & 0.40 \\
\hline D & 0.81 & 0.10 & 0.71 & 0.19 & 0.76 & 0.09 & 0.67 & 0.24 \\
\hline $\mathbf{E}$ & 0.99 & 0.10 & 0.89 & 0.01 & 0.71 & 0.10 & 0.61 & 0.29 \\
\hline $\mathbf{F}$ & 0.58 & 0.02 & 0.56 & 0.42 & 0.32 & 0.01 & 0.30 & 0.68 \\
\hline $\mathbf{G}$ & 0.38 & 0.04 & 0.35 & 0.62 & 0.32 & 0.03 & 0.29 & 0.68 \\
\hline H & 0.25 & 0.01 & 0.24 & 0.75 & 0.43 & 0.14 & 0.29 & 0.57 \\
\hline I & 0.45 & 0.00 & 0.45 & 0.55 & 0.66 & 0.05 & 0.62 & 0.34 \\
\hline $\mathbf{J}$ & 0.70 & 0.23 & 0.47 & 0.30 & 0.69 & 0.19 & 0.50 & 0.31 \\
\hline $\mathbf{K}$ & 0.31 & 0.03 & 0.28 & 0.69 & 0.48 & 0.05 & 0.43 & 0.52 \\
\hline
\end{tabular}

Source: Our calculations using the CHELEM - CEPII database 
Table 5: Exports, imports and trade balance for Romania and Bulgaria vis-à-vis the EU15 (2006, million dollars)

\begin{tabular}{|l|l||r|r|r||r|r|r|}
\hline \multirow{2}{*}{ Code } & \multirow{2}{*}{ Sector } & \multicolumn{3}{|c||}{ Romania } & \multicolumn{3}{c|}{ Bulgaria } \\
\cline { 2 - 7 } & Export & Import & Balance & Export & Import & Balance \\
\hline \hline Total & Total & 17577.4 & 27371.8 & -9794.4 & 7279.9 & 9349.4 & -2069.5 \\
\hline B & Building materials & 110.4 & 346.0 & -235.6 & 87.4 & 163.1 & -75.7 \\
\hline C & Iron and steel industry & 949.0 & 1141.2 & -192.2 & 1713.9 & 460.1 & 1253.7 \\
\hline D & Textiles, leathers & 6522.0 & 4344.5 & 2177.6 & 2121.4 & 1488.5 & 632.8 \\
\hline E & Woods and paper & 1598.9 & 1241.4 & 357.4 & 337.5 & 456.1 & -118.6 \\
\hline F & Electric and mechanics & 6118.5 & 14690.0 & -8571.4 & 1369.0 & 4332.9 & -2963.9 \\
\hline G & Chemicals & 893.7 & 3599.0 & -2705.3 & 381.9 & 1320.1 & -938.1 \\
\hline H & Minerals & 229.3 & 68.4 & 160.9 & 272.2 & 44.5 & 227.7 \\
\hline I & Energy & 376.8 & 196.9 & 179.8 & 339.8 & 307.8 & 32.0 \\
\hline J & Agriculture & 495.9 & 379.5 & 116.4 & 367.1 & 169.3 & 197.8 \\
\hline K & Food & 138.2 & 846.3 & -708.1 & 221.8 & 417.4 & -195.5 \\
\hline NDA & N.D.A. & 144.7 & 518.6 & -373.9 & 68.0 & 189.7 & -121.6 \\
\hline
\end{tabular}

Source: Our calculations using the CHELEM - CEPII database 
Table 6a: Estimated trade flows between EEC-2 and EU-15 over the whole sample and two subperiods using static panel data methods

\begin{tabular}{|c|c|c|c|c|c|c|c|c|c|}
\hline \multirow{4}{*}{ Variables } & \multicolumn{3}{|c|}{$1990-2006$} & \multicolumn{3}{|c|}{1990 - 1999} & \multicolumn{3}{|c|}{$2000-2006$} \\
\hline & FEM & REM & FEVD & FEM & REM & FEVD & FEM & REM & FEVD \\
\hline & (1) & (2) & (3) & (4) & (5) & (6) & (7) & (8) & (9) \\
\hline & $\mathbf{x}_{\mathrm{ii}}$ & $\mathbf{x}_{\mathrm{ij}}$ & $\mathbf{x}_{\mathrm{ii}}$ & $\mathbf{x}_{\mathrm{ii}}$ & $\mathbf{x}_{\mathrm{ii}}$ & $\mathbf{x}_{\mathrm{ij}}$ & $\mathbf{x}_{\mathrm{ii}}$ & $\mathbf{x}_{\mathrm{ij}}$ & $\mathbf{x}_{\mathrm{ii}}$ \\
\hline \multirow[t]{2}{*}{$\overline{\mathrm{GDP}_{\text {it }}}$} & 1.432 & 1.444 & 1.432 & 2.215 & 0.849 & 2.215 & 1.868 & 2.013 & 1.868 \\
\hline & $(11.13)^{* * *}$ & $(18.82)^{* * *}$ & $(11.88)^{* * *}$ & $(9.21)^{* * *}$ & $(8.50) * * *$ & $(9.77)^{* * *}$ & $(7.17)^{* * *}$ & $(21.26)^{* * *}$ & $(20.32)^{* * *}$ \\
\hline \multirow[t]{2}{*}{$\mathrm{GDP}_{\mathrm{jt}}$} & 2.637 & 1.628 & 2.637 & 2.722 & 0.841 & 2.722 & 3.621 & 2.045 & 3.621 \\
\hline & $(20.50)^{* * *}$ & $(21.22)^{* * *}$ & $(21.74)^{* * *}$ & $(11.32)^{* * *}$ & $(8.41)^{* * *}$ & $(11.92)^{* * *}$ & $(12.64)^{* * *}$ & $(21.59)^{* * *}$ & $(39.77)^{* * *}$ \\
\hline \multirow[t]{2}{*}{ Dist $_{\mathrm{ij}}$} & 0.000 & -2.144 & -2.143 & 0.000 & -2.050 & -2.014 & 0.000 & -2.263 & -2.311 \\
\hline & (.) & $(9.07)^{* * *}$ & $(59.22)$ & (.) & $(8.63)^{* * *}$ & $(32.13)^{* * *}$ & (.) & $(7.66)^{* * *}$ & $(38.28)^{* * *}$ \\
\hline \multirow[t]{2}{*}{ DGDPT $_{i j t}$} & 0.023 & 0.022 & 0.023 & 0.114 & 0.326 & 0.114 & -0.085 & 0.003 & -0.085 \\
\hline & $(1.84)^{*}$ & $(0.59)$ & $(2.11)^{*}$ & $(1.81)^{*}$ & $(4.79)^{* * *}$ & $(1.72)^{*}$ & $(2.03)^{*}$ & $(3.11)^{* * *}$ & $(1.95)^{*}$ \\
\hline \multirow{2}{*}{$\mathrm{RCS}_{\mathrm{ijt}}$} & -0.821 & 0.006 & -0.821 & -3.248 & -1.070 & -3.248 & 0.120 & 0.964 & 0.120 \\
\hline & $(3.55)^{* * *}$ & $(0.05)$ & $(44.50)^{* * *}$ & $(14.54)^{* * *}$ & $(7.80)^{* * *}$ & $(80.20)^{* * *}$ & $(5.42)^{* * *}$ & $(6.21)^{* * *}$ & $(12.58)^{* * *}$ \\
\hline \multirow[t]{2}{*}{$\operatorname{Acc}_{i j t}$} & 0.255 & 0.336 & 0.255 & - & - & - & - & - & - \\
\hline & $(13.51)^{* * *}$ & $(21.63)^{* * *}$ & $(7.86) * * *$ & & & & & & \\
\hline \multirow[t]{2}{*}{ Residuals } & - & - & 1.000 & - & - & 1.000 & - & - & 0.923 \\
\hline & & & $(142.10)^{* * *}$ & & & $(199.87)^{* * *}$ & & & $(288.77)^{* * *}$ \\
\hline \multirow{2}{*}{ Constant } & -19.827 & -7.497 & -12.946 & -26.202 & -2.362 & -19.736 & -23.194 & -11.277 & -18.866 \\
\hline & $(22.42)^{* * *}$ & $(7.76)^{* * *}$ & $(123.84)^{* * *}$ & $(12.35)^{* * *}$ & $(2.02)^{* *}$ & $(152.13)^{* * *}$ & $(14.14)^{* * *}$ & $(9.46)^{* * *}$ & $(282.21)^{* * *}$ \\
\hline Observations & 952 & 952 & 952 & 560 & 560 & 560 & 392 & 392 & 392 \\
\hline Number of groups & 56 & 56 & - & 56 & 56 & - & 56 & 56 & - \\
\hline R-squared & 0.72 & 0.73 & 0.95 & 0.42 & 0.78 & 0.95 & 0.76 & 0.70 & 0.99 \\
\hline \multirow{2}{*}{$\begin{array}{l}\text { Fischer } \\
\text { Prob }>\text { F }\end{array}$} & 48.74 & - & - & 28.36 & - & - & 90.70 & - & - \\
\hline & $(0.00)$ & & & $(0.00)$ & & & $(0.00)$ & & \\
\hline \multirow{2}{*}{$\begin{array}{l}\text { Hausman } \\
\text { Prob }>\text { chi2 }\end{array}$} & - & 892.13 & - & - & 173.33 & - & - & 466.84 & - \\
\hline & & $(0.00)$ & & & $(0.00)$ & & & $(0.00)$ & \\
\hline \multicolumn{10}{|c|}{ Absolute value of $t$ statistics in parentheses } \\
\hline cant at $10 \%$ & 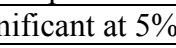 & & & & & & & & \\
\hline
\end{tabular}


Table 6b: Estimated trade flows between EEC-2 and EU-15 over the whole sample and two subperiods using the GMM dynamic panel data method

\begin{tabular}{|c|c|c|c|}
\hline \multirow{3}{*}{ Variable } & 1990-2006 & 1990-1999 & 2000-2006 \\
\hline & (1) & $(2)$ & (3) \\
\hline & $\mathbf{x}_{\mathrm{ij}}$ & $\mathbf{x}_{\mathrm{ij}}$ & $\mathbf{x}_{\mathrm{ij}}$ \\
\hline \multirow{2}{*}{$\mathrm{LX}_{\mathrm{ij}-1}$} & 0.853 & 0.696 & 0.881 \\
\hline & $(101.57)^{* * *}$ & $(39.17)^{* * *}$ & $(28.47)^{* * *}$ \\
\hline \multirow{2}{*}{$\mathrm{GDP}_{\text {it }}$} & 0.307 & 0.317 & 0.397 \\
\hline & $(9.21)^{* * *}$ & $(9.15)^{* * *}$ & $(7.04)^{* * *}$ \\
\hline \multirow[t]{2}{*}{$\mathrm{GDP}_{\mathrm{jt}}$} & 0.304 & 0.291 & 0.364 \\
\hline & $(8.14)^{* * *}$ & $(8.64)^{* * *}$ & $(3.42)^{* * *}$ \\
\hline \multirow{2}{*}{ Dist $_{\mathrm{ij}}$} & -0.304 & -0.658 & -0.268 \\
\hline & $(3.40) * * *$ & $(12.49)^{* * *}$ & $(3.88) * * *$ \\
\hline \multirow[t]{2}{*}{ DGDPT $_{i j t}$} & 0.018 & 0.031 & -0.010 \\
\hline & $(3.00) * * *$ & $(1.97)^{*}$ & $(3.33) * * *$ \\
\hline \multirow[t]{2}{*}{$\mathrm{RCS}_{\mathrm{ijt}}$} & -0.079 & -0.298 & 0.241 \\
\hline & $(2.67)^{* * *}$ & $(7.37)^{* * *}$ & $(5.63)^{* * *}$ \\
\hline \multirow[t]{2}{*}{$\mathrm{Acc}_{\mathrm{ijt}}$} & 0.061 & 0.084 & - \\
\hline & $(17.12)^{* * *}$ & $(17.17)^{* * *}$ & \\
\hline \multirow[t]{2}{*}{ Constant } & -2.040 & -0.816 & -2.633 \\
\hline & $(4.77)^{* * *}$ & $(3.03)^{* * *}$ & $(6.00)^{* * *}$ \\
\hline Observations & 952 & 560 & 392 \\
\hline Number of cod_rel & 56 & 56 & 56 \\
\hline \multirow{2}{*}{$\begin{array}{l}\text { Hansen test of overidentification } \\
\text { Prob }>\text { chi } 2\end{array}$} & 55.24 & 53.36 & 53.86 \\
\hline & $(1.00) * * *$ & $(0.95)^{* * *}$ & $(1.00)^{* * *}$ \\
\hline \multirow{2}{*}{$\begin{array}{l}\text { Arellano-Bond test for AR(2) } \\
\text { Prob }>\mathrm{z}\end{array}$} & 0.60 & 0.66 & -0.69 \\
\hline & $(0.55)^{* * *}$ & $(0.51)^{* * *}$ & $(0.49)^{* * *}$ \\
\hline
\end{tabular}


Table 7: Estimated impact of intermediate goods on the exports of EEC-2 to EU-15

\begin{tabular}{|c|c|c|c|c|}
\hline \multirow{3}{*}{ Variable } & FEM & REM & FEVD & GMM \\
\hline & (1) & (2) & (3) & (4) \\
\hline & $\mathbf{x}_{\mathrm{ij}}$ & $\mathbf{x}_{\mathrm{ij}}$ & $\mathbf{x}_{\mathrm{ij}}$ & $\mathbf{x}_{\mathrm{ij}}$ \\
\hline \multirow{2}{*}{ L. $\mathrm{X}_{\mathrm{ij}}$} & - & - & - & 0.685 \\
\hline & & & & $(10.09)^{* * *}$ \\
\hline \multirow[t]{2}{*}{$\mathrm{GDP}_{\text {it }}$} & 1.884 & 0.913 & 1.884 & 0.371 \\
\hline & $(8.65)^{* * *}$ & $(5.31)^{* * *}$ & $(9.01)^{* * *}$ & $(1.90)^{*}$ \\
\hline \multirow[t]{2}{*}{$\mathrm{GDP}_{\mathrm{jt}}$} & 1.776 & 1.351 & 1.776 & 0.272 \\
\hline & $(8.56)^{* * *}$ & $(8.34)^{* * *}$ & $(8.75)^{* * *}$ & $(2.30)^{* *}$ \\
\hline \multirow[t]{2}{*}{ Dist $_{\mathrm{ij}}$} & 0.000 & -1.637 & -1.675 & -1.168 \\
\hline & $()$. & $(7.62)^{* * *}$ & $(38.53)^{* * *}$ & $(2.03)^{*}$ \\
\hline \multirow{2}{*}{ DGDPT $_{\text {ijt }}$} & 0.006 & 0.026 & 0.006 & 0.143 \\
\hline & $(0.13)$ & $(0.56)$ & $(0.02)$ & $(2.41)^{* *}$ \\
\hline \multirow{2}{*}{$\mathrm{RCS}_{\mathrm{ijt}}$} & -1.261 & 0.108 & -1.261 & -0.409 \\
\hline & $(3.98)^{* * *}$ & $(0.43)$ & $(46.49)^{* * *}$ & $(1.83)^{*}$ \\
\hline \multirow{2}{*}{ Mint $_{\text {ijt }}$} & 0.200 & 0.210 & 0.200 & 0.125 \\
\hline & $(7.06)^{* * *}$ & $(7.50)^{* * *}$ & $(8.08)^{* * *}$ & $(9.12)^{* * *}$ \\
\hline \multirow[t]{2}{*}{$\operatorname{Acc}_{\mathrm{ijt}}$} & 0.174 & 0.269 & 0.174 & 0.061 \\
\hline & $(6.94)^{* * *}$ & $(12.21)^{* * *}$ & $(4.56) * * *$ & $(4.32)^{* * *}$ \\
\hline \multirow[t]{2}{*}{ Residuals } & - & - & 1.000 & - \\
\hline & & & $(101.91)^{* * *}$ & \\
\hline \multirow[t]{2}{*}{ Constant } & -18.289 & -5.305 & -12.912 & 0.000 \\
\hline & $(15.07)^{* * *}$ & $(5.27)^{* * *}$ & $(105.58)^{* * *}$ & $()$. \\
\hline Observations & 476 & 476 & 476 & 476 \\
\hline Number of groups & 28 & 28 & - & 28 \\
\hline R-squared & 0.82 & 0.85 & 0.96 & - \\
\hline \multirow{2}{*}{$\begin{array}{l}\text { Fischer } \\
\text { Prob }>\text { F }\end{array}$} & 31.34 & - & - & - \\
\hline & $(0.00)$ & & & \\
\hline \multirow{2}{*}{$\begin{array}{l}\text { Hausman } \\
\text { Prob }>\text { chi2 }\end{array}$} & - & 33.67 & - & - \\
\hline & & $(0.00)$ & & \\
\hline \multirow{2}{*}{$\begin{array}{l}\text { Hansen test of overidentification } \\
\text { Prob > chi } 2\end{array}$} & - & - & - & 26.49 \\
\hline & & & & $(1.00)^{* * *}$ \\
\hline \multirow{2}{*}{$\begin{array}{l}\text { Arellano-Bond test for AR(2) } \\
\text { Prob }>\text { z }\end{array}$} & - & - & - & -0.28 \\
\hline & & & & $(0.78)^{* * *}$ \\
\hline \multicolumn{5}{|c|}{ Absolute value of $\mathrm{t}$ statistics in parentheses } \\
\hline \multicolumn{5}{|c|}{$*$ significant at $10 \% ; * *$ significant at $5 \% ; * * *$ significant at $1 \%$} \\
\hline
\end{tabular}




\section{DAVIDSON INSTITUTE WORKING PAPER SERIES - Most Recent Papers}

The entire Working Paper Series may be downloaded free of charge at: www.wdi.umich.edu

CURRENT AS OF 6/12/09

\begin{tabular}{|c|c|c|}
\hline Publication & Authors & Date \\
\hline $\begin{array}{l}\text { No. 959: Trade Specialisation And Economic Convergence: } \\
\text { Evidence From Two Eastern European Countries }\end{array}$ & $\begin{array}{l}\text { Christophe Rault, Guglielmo } \\
\text { Caporale, Robert Sova \& } \\
\text { Anamaria Sova }\end{array}$ & June 2009 \\
\hline $\begin{array}{l}\text { No. 958: Inflation differentials in the Euro area and their determinants } \\
\text { - an empirical view }\end{array}$ & $\begin{array}{c}\text { Juan Ignacio Aldasoro \& Václav } \\
\text { Žd'árek }\end{array}$ & April 2009 \\
\hline No. 957: Infrastructure and growth: Empirical evidence & $\begin{array}{c}\text { Balazs Egert, Tomasz } \\
\text { Kozluk and Douglas Sutherland }\end{array}$ & April 2009 \\
\hline $\begin{array}{l}\text { No. 956: Infrastructure investment in network industries: The role of } \\
\text { incentive regulation and regulatory independence }\end{array}$ & Balazs Egert & April 2009 \\
\hline $\begin{array}{l}\text { No. 955: The impact of monetary and commodity fundamentals, macro } \\
\text { news and central bank communication on the exchange rate: } \\
\text { Evidence from South Africa }\end{array}$ & Balazs Egert & April 2009 \\
\hline $\begin{array}{l}\text { No. 954: "Family" ownership, tunneling and earnings management: } \\
\text { A review of the literature }\end{array}$ & $\begin{array}{l}\text { Sumon Bhaumik and Andros } \\
\text { Gregoriou }\end{array}$ & $\begin{array}{l}\text { March } \\
2009\end{array}$ \\
\hline $\begin{array}{l}\text { No. 953: Impact of Foreign Direct Investments on Industrial Productivity: } \\
\text { A Subnational Study of India }\end{array}$ & Krishna C. Vadlamannati & $\begin{array}{c}\text { March } \\
2009\end{array}$ \\
\hline $\begin{array}{l}\text { No. 952: Determinants of Exchange Rate Practices in the MENA } \\
\text { Countries: Some Further Empirical Results }\end{array}$ & Sfia, M. Daly and Mouley Sami & Jan 2009 \\
\hline No. 951: An Analytic Approach To Selecting A Nonprofit & $\begin{array}{l}\text { Andrés Ramírez and } \\
\text { Hakan Saraoglu }\end{array}$ & Jan 2009 \\
\hline $\begin{array}{l}\text { No. 950: Anthropometry of Love } \\
\text { Height and Gender Asymmetries in Interethnic Marriages }\end{array}$ & Michèle Belot and Jan Fidrmuc & Jan 2009 \\
\hline No. 949: IS THE COST OF LIVING IN RUSSIA REALLY THAT LOW? & Konstantin Gluschenko & Dec 2008 \\
\hline $\begin{array}{l}\text { No. 948: Banking Market Liberalization and Bank Performance: the Role } \\
\text { of Entry Modes }\end{array}$ & Ngoc-Anh Vo Thi & Jan 2009 \\
\hline $\begin{array}{l}\text { No. 947: The Monetary Union: The Decade Ahead. } \\
\text { The Case of Non-Member States }\end{array}$ & Daniel Daianu and Laurian Lungu & Jan 2009 \\
\hline No. 946: Currency Substitution: A Case Of Kazakhstan (2000:1-2007:12) & $\begin{array}{l}\text { Mesut Yilmaz, Yessengali } \\
\text { Oskenbayev \& Kanat Abdulla }\end{array}$ & Jan 2009 \\
\hline $\begin{array}{l}\text { No. 945: Determinants Of Pollution Abatement And Control Expenditure: } \\
\text { Evidence From Romania }\end{array}$ & $\begin{array}{l}\text { Guglielmo Caporale, Christophe } \\
\text { Rault, Robert Sova \& Anamaria } \\
\text { Sova }\end{array}$ & Jan 2009 \\
\hline $\begin{array}{l}\text { No. 944: Bootstrap panel Granger-causality between government } \\
\text { spending and revenue in the EU }\end{array}$ & $\begin{array}{l}\text { Antonio Afonso and Christophe } \\
\text { Rault }\end{array}$ & Jan 2009 \\
\hline No. 943: Regional Determinants of FDI Distribution in Poland & $\begin{array}{l}\text { Agnieszka Chidlow and Stephen } \\
\text { Young }\end{array}$ & Nov 2008 \\
\hline No. 942: Structural Reform and Firm Exports & $\begin{array}{l}\text { Alvaro Cuervo-Cazurra \& Luis } \\
\text { Alfonso Dau }\end{array}$ & Sept 2008 \\
\hline $\begin{array}{l}\text { No. 941: Exploring The Relationship Between Military Spending \& } \\
\text { Human Rights Performance In South Asia }\end{array}$ & $\begin{array}{l}\text { Krishna Chaitanya, Vadlamannati } \\
\text { and K K Shakya Lahiru Pathmalal }\end{array}$ & Oct 2008 \\
\hline $\begin{array}{l}\text { No. 940: Structural Reform And Firm Profitability In Developing } \\
\text { Countries }\end{array}$ & $\begin{array}{l}\text { Alvaro Cuervo-Cazurra \& Luis } \\
\text { Alfonso Dau }\end{array}$ & July 2008 \\
\hline $\begin{array}{l}\text { No. 939: Does Timing Of Elections Instigate Riots? } \\
\text { A Subnational Study Of } 16 \text { Indian States, } 1958 \text { - } 2004\end{array}$ & Krishna Chaitanya Vadlamannati & Oct 2008 \\
\hline $\begin{array}{l}\text { No. 938: Price Setting And Market Structure: An Empirical Analysis Of } \\
\text { Micro Data }\end{array}$ & Fabrizio Coricelli \& Roman Horvath & Sept 2008 \\
\hline $\begin{array}{l}\text { No. 937: Inflation Differentials in EU New Member States: An Empirical } \\
\text { Evidence }\end{array}$ & Roman Horvath \& Kamila Koprnicka & Oct 2008 \\
\hline $\begin{array}{l}\text { No. 936: Market Reforms and Growth in Post-socialist Economies: } \\
\text { Evidence from Panel Cointegration and Equilibrium Correction Model }\end{array}$ & Igor Pelipas and Alexander Chubrik & Sept 2008 \\
\hline
\end{tabular}

